\title{
Effects of an Angiotensin I-Converting Enzyme Inhibitor (SA-446) on Renal Function in Dogs
}

\author{
Toyokazu TAKADA, Kenjiro YAMAMOTO, Shoji FUJIOKA*, \\ Toshiaki TAMAKI*, Kiyoshi FUKUI* and Youichi ABE* \\ Department of Pharmacology. Osaka City University Medıcal School. Osaka 545, Japan \\ *Department of Pharmacology. Kagawa Medical School. Kagawa 761-07. Japan
}

Accepted March 29, 1985

\begin{abstract}
The effects of an orally active inhibitor of angiotensin-converting enzyme (SA-446) on systemic arterial pressure, renal function and renin release were examined in anesthetized dogs. Intrarenal infusion of the larger dose of SA-446 $(0.1 \mathrm{mg} / \mathrm{min})$ caused an increase in RBF, urine flow and renin release and caused a fall in blood pressure. The smaller dose of SA-446 $(0.02 \mathrm{mg} / \mathrm{min})$ did not affect the blood pressure, but it increased the urine flow. However, the same dose of SA-446 in combination with probenecid caused a significant fall in blood pressure. The potentiation of SA-446 with probenecid may be explained by the elevation in plasma SA-446 concentration via the inhibition of its tubular secretion by probenecid.
\end{abstract}

SA-446 ((2R, 4R)-2-(2-hydroxyphenyl)3-(3-mercaptopropionyl)-4-thiazolidinecarboxylic acid) is a newly developed converting enzyme inhibitor (1) which has an antihypertensive effect in laboratory animals (2). The antihypertensive mechanisms of SA446 seem to be related to the inhibition of the conversion of angiotensin I to the physiologically active pressor octapeptide, angiotensin 11 , and the potentiation of biological action of bradykinin. However, there are few reports on the effects of the angiotensinconverting enzyme inhibitors on renal function, urine flow, and urinary excretion of sodium-all major determinants of blood pressure. The present study was designed to determine the effects of SA-446 on renal hemodynamics, urine formation, and renin release in anesthetized dogs. Since we have previously reported that SA-446 was excreted via organic anion transport systems (3), the modification of the renal action of SA-446 in the presence or absence of probenecid, a competitive inhibitor of organic anion secretory transport (4), was also examined.

Experiments were carried out using mongrel dogs of both sexes weighing 10$14 \mathrm{~kg}$ which had been maintained on standard laboratory chow for 1 week. All dogs were deprived of food for $24 \mathrm{hr}$ before the experiments were begun. The animals were anesthetized with sodium pentobarbital $(30 \mathrm{mg} /$ $\mathrm{kg}$. i.v.). The left kidney was exposed through a retroperitoneal flank incision. The kidney was carefully denervated, and renal blood flow (RBF) was measured by an electromagnetic flow meter. A 23 -gauge needle was inserted into the left renal artery proximal to the flow probe for intrarenal infusion of saline and SA-446 at a rate of $0.5 \mathrm{ml} / \mathrm{min}$. Glomerular filtration rate (GFR) was measured by the creatinine clearance. A polyethylene catheter was inserted into the left ureter for urine collection.

After completion of surgery, the dog was left alone for $60-90 \mathrm{~min}$ to allow for stabilization of systemic blood pressure, RBF, and urine flow. Urine was then collected during three consecutive 10-min control clearance periods. At the midpoint of each period. systemic arterial and renal venous blood was collected from the right brachial artery and from the left renal vein via a catheter inserted through the left spermatic or ovarian vein. After the control periods, SA-446 was infused into the renal artery for $30 \mathrm{~min}$ in doses of 0.1 and $0.02 \mathrm{mg} / \mathrm{min}$. Urine and blood samples were collected for three 
consecutive 10-min clearance periods. Following the $30 \mathrm{~min}$ infusion of SA-446. saline was infused into the renal artery to assess the effectiveness of the drug. In 5 dogs, SA-446 was administered at a rate of $0.02 \mathrm{mg} / \mathrm{min}$ for $30 \mathrm{~min}$, and urine and blood samples were taken in the same way as described above. In another 5 dogs, a priming dose of probenecid ( $30 \mathrm{mg} / \mathrm{kg}$ ) was injected intravenously, followed by a sustaining dose at a rate of $20 \mathrm{mg} / \mathrm{kg} \cdot \mathrm{hr}$. Blood samples were obtained at $30 \mathrm{~min}$ after starting the administration of probenecid, and urine samples were obtained between 25 and $35 \mathrm{~min}$ after the initiation of infusion of probenecid. Then SA-446 was infused into the renal artery for $30 \mathrm{~min}$ at a rate of 0.02 $\mathrm{mg} / \mathrm{min}$, and urine and blood samples were collected for three consecutive 10-min clearance periods. Plasma renin activity (PRA) was determined by radioimmunoassay of angiotensin I (5) and expressed as nano- grams of angiotensin I per millititer per hour.

Table 1 shows the effects of intrarenal infusion of SA-446 on renal hemodynamics. urine flow and renal venous PRA. SA-446 infusion at a rate of $0.1 \mathrm{mg} / \mathrm{min}$ resulted in a significant increase in RBF, urine flow and urinary excretion of sodium and in a significant fall in systemic arterial pressure. These responses reached a maximum about $20 \mathrm{~min}$ after the start of infusion and remained at the same level for the consecutive periods. Urine flow and urinary excretion of sodium increased approximately $50 \%$ without any significant change in GFR. Data are not shown in Table 1, but osmolar clearance and free water reabsorption increased almost proportionally. Renal venous PRA gradually increased and the calculated renin secretion rate increased about 2 - to 3 -fold.

Table 2 shows the renal effects of the smaller dose of SA-446 and the effects of SA-446 infusion in combination with pro-

Table 1. Effects of the larger dose of SA-446 on renal function and renal venous PRA $(n=8)$

\begin{tabular}{|c|c|c|c|c|c|c|c|}
\hline & $\begin{array}{l}\text { Time } \\
\text { min }\end{array}$ & $\begin{array}{c}\mathrm{BP} \\
\mathrm{mmHg}\end{array}$ & $\begin{array}{l}\text { RBF } \\
\mathrm{ml} / \mathrm{g} \cdot \min \end{array}$ & $\begin{array}{c}\mathrm{GFR} \\
\mathrm{m} / \mathrm{g} \cdot \min \end{array}$ & $\begin{array}{l}\text { UF } \\
\mu / / g \cdot \min \end{array}$ & $\begin{array}{c}U_{\mathrm{NaV}} \\
\mu \mathrm{Eq} / \mathrm{g} \cdot \mathrm{min}\end{array}$ & $\begin{array}{c}\text { PRA } \\
\mathrm{ng} / \mathrm{ml} \cdot \mathrm{hr}\end{array}$ \\
\hline Control & 0 & $124 \pm 3$ & $3.17 \pm 0.34$ & $0.74 \pm 0.06$ & $20 \pm 4$ & $3.4 \pm 0.7$ & $2.1 \pm 0.6$ \\
\hline $\mathrm{SA}-446$ & 10 & $115 \pm 6^{*}$ & $3.56 \pm 0.41^{*}$ & $0.73 \pm 0.06$ & $30 \pm 5$ & $5.2 \pm 1.1^{*}$ & $4.5 \pm 1.6^{*}$ \\
\hline \multirow[t]{2}{*}{$(0.1 \mathrm{mg} / \mathrm{min})$} & 20 & $113 \pm 5^{*}$ & $3.62 \pm 0.40^{*}$ & $0.71 \pm 0.05$ & $32 \pm 5^{*}$ & $5.4 \pm 1.0^{*}$ & $4.4 \pm 1.5^{*}$ \\
\hline & 30 & $111 \pm 5^{*}$ & $3.65 \pm 0.39^{*}$ & $0.73 \pm 0.06$ & $31 \pm 4^{*}$ & $5.1 \pm 0.9$ & $5.0 \pm 1.9^{*}$ \\
\hline
\end{tabular}

All values are means $\pm S$. E. $n=$ number of dogs tested, $B P=$ systemic arterial pressure, $R B F=$ renal blood flow, GFR=glomerular filtration rate, UF=urine flow, $U_{N a} V=$ urinary excretion of sodium, PRA=plasma renin activity in renal venous blood. *indicates significance of the difference between control and experimental periods $(P<0.05)$.

Table 2. Effects of the smaller dose of SA-446 on renal function and renal venous PRA before and after treatment of probenecid $(n=5)$

\begin{tabular}{|c|c|c|c|c|c|c|c|}
\hline & $\begin{array}{l}\text { Time } \\
\min \end{array}$ & $\begin{array}{c}\mathrm{BP} \\
\mathrm{mmHg}\end{array}$ & $\begin{array}{c}\text { RBF } \\
\mathrm{ml} / \mathrm{g} \cdot \min \end{array}$ & $\begin{array}{c}\mathrm{GFR} \\
\mathrm{ml} / \mathrm{g} \cdot \mathrm{min}\end{array}$ & $\begin{array}{l}\text { UF } \\
\mu / / g \cdot \min \end{array}$ & $\begin{array}{c}U_{\mathrm{N} V} V \\
\mu \mathrm{Eq} / g \cdot \mathrm{min}\end{array}$ & $\begin{array}{c}\text { PRA } \\
n g / m / n r\end{array}$ \\
\hline Control & 0 & $128 \pm 9$ & $2.98 \pm 0.27$ & $0.73 \pm 0.05$ & $8 \pm 1$ & $1.7 \pm 0.3$ & $2.1 \pm 0.4$ \\
\hline SA-446 & 10 & $128 \pm 9$ & $3.20 \pm 0.29$ & $0.73 \pm 0.07$ & $13 \pm 3$ & $3.0 \pm 0.8$ & $2.0 \pm 0.4$ \\
\hline \multirow[t]{2}{*}{$(0.02 \mathrm{mg} / \mathrm{min})$} & 20 & $124 \pm 9$ & $3.52 \pm 0.31^{*}$ & $0.75 \pm 0.08$ & $18 \pm 5^{*}$ & $3.9 \pm 1.1^{*}$ & $3.0 \pm 1.0$ \\
\hline & 30 & $123 \pm 9$ & $3.67 \pm 0.36^{*}$ & $0.73 \pm 0.08$ & $20 \pm 6^{*}$ & $4.2 \pm 1.3^{*}$ & $3.3 \pm 1.1$ \\
\hline Control & -35 & $125 \pm 4$ & $3.57 \pm 0.25$ & $0.72 \pm 0.08$ & $14 \pm 5$ & $3.6 \pm 1.1$ & $3.3 \pm 1.0$ \\
\hline Probenecid & 0 & $128 \pm 5$ & $3.73 \pm 0.28$ & $0.74 \pm 0.09$ & $18 \pm 6$ & $4.1 \pm 1.4$ & $3.3 \pm 1.0$ \\
\hline$S A-446$ & 10 & $121 \pm 5$ & $4.61 \pm 0.25^{*}$ & $0.78 \pm 0.06$ & $25 \pm 8^{*}$ & $5.6 \pm 1.6$ & $5.5 \pm 2.2$ \\
\hline \multirow[t]{2}{*}{$(0.02 \mathrm{mg} / \mathrm{min})$} & 20 & $117 \pm 6^{*}$ & $4.80 \pm 0.20^{*}$ & $0.79 \pm 0.08$ & $27 \pm 9^{*}$ & $5.9 \pm 1.8^{*}$ & $6.4 \pm 2.5^{*}$ \\
\hline & 30 & $115 \pm 6^{*}$ & $4.89 \pm 0.29^{*}$ & $0.85 \pm 0.07$ & $24 \pm 9^{*}$ & $5.2 \pm 1.5$ & $9.2 \pm 4.1^{*}$ \\
\hline
\end{tabular}

Ali values are means \pm S.E. $n=$ number of dogs tested. "indicates significance of the difference $(P<0.05)$.

See legend to Table 1 for abbreviations. 
benecid. The smaller dose of SA-446: 0.02 $\mathrm{mg} / \mathrm{min}$ ) slightly decreased the systemic arterial pressure and slightly increased the renal venous PRA. These changes were not statistically significant. However. RBF, urine flow and urinary excretion of sodium significantly increased. Intravenous administration of probenecid in a dose of $30 \mathrm{mg} / \mathrm{kg}$ and at a rate of $20 \mathrm{mg} / \mathrm{kg} \cdot \mathrm{hr}$ in itself did not affect RBF, GFR, urine flow and renal venous PRA. Infusing the same dose of SA446 during probenecid infusion resulted in a significant fall in systemic arterial pressure and in a significant increase in renal venous PRA in contrast to the results observed in the absence of probenecid. Urine flow and urinary excretion of sodium were also increased by the SA-446 infusion in combination with probenecid, but these changes were not significantly different from those recorded when only SA-446 was administered.

SA-446, a newly-synthesized sulfhydryl compound, inhibited the angiotensinconverting enzyme purified from rabbit lung. The inhibitory action was 4-5 times greater than that of captopril (2). The larger dose of SA-446 $(0.1 \mathrm{mg} / \mathrm{min})$ caused an increase in RBF, urine flow, and renin release. Systemic arterial pressure decreased about $15 \mathrm{mmHg}$ 30 min after the start of infusion. Urine flow and urinary excretion of sodium increased without any change in GFR. Osmolar clearance and free water reabsorption increased proportionally, indicating that SA446 has little effect on the medullary portion of the ascending limb of Henle and may have a proximal site of action. Bailie and Barbour (6) and we (7) reported similar results with SO 20.881 and $Y S-980$ which have inhibitory action on an angiotensinconverting enzyme. The smaller dose of SA$446(0.02 \mathrm{mg} / \mathrm{min})$ also caused an increase in RBF, urine flow and urinary excretion of sodium, but did not affect the systemic arterial pressure and renal venous PRA. The same dose of SA-446 in combination with probenecid caused a significant fall in blood pressure. However, the changes in urine flow and in the urinary excretion of sodium were not modified by probenecid. Since converting enzyme inhibitors such as captopril and SA-
446 are weak organic anions $(3,8)$, and SA446 has a structural resemblance to penicillin. the renal excretion of SA-446 is markedly inhibited by probenecid (3). The potentiation of its hypotensive action may be explained by the elevation in plasma SA-446 concentration via the inhibition of its tubular secretion by probenecid. However, it is difficult to explain why the effects of SA-446 on the urine flow and the urinary excretion of sodium were not potentiated by probenecid. In general. the hypotension should induce antidiuresis. Thus, it can be considered that the potentiatory actions of probenecid on urine formation might be masked by the hypotension observed in the SA-446 infusion in combination with probenecid.

Acknowlegments: We are gratefull to $Y$. Fujisawa and $\mathrm{H}$. Irie for excellent technical assistance, to J. Beeler for reading the manuscript, and to T. Akiyama for secretarial services.

\section{References}

1 Oya, M., Baba, T., Kato, E., Kawashima. Y. and Watanabe, T.: Synthesis and antihypertensive activity of $\mathrm{N}$-(mercaptoacyl)-thiazolidinecarboxy ic acids. Chem. Pharm. Bull. (Tokyo) 30 . 440-461 (1981)

2 Iso, T., Yamauchi, H., Suda, H., Nakata, K., Nishimura, $K$. and Iwao, J.: A new potent inhibitor of converting enzyme: (2R, 4R)-2-(2hydroxyphenyl) - 3-(3-mercaptopropionyl)-4thiazolidinecarboxylic acid (SA-446). Japan. J. Pharmacol. 31, 875-882 (1982)

3 Abe, Y., Okahara, T., Miura, K., Yukimura, T., Takada, T., Iwatani, T., Iso, T. and Yamamoto, K.: Renal excretion of an angiotensin 1-converting enzyme inhibitor (SA-446) in dogs. Naunyn Schmiedebergs Arch. Pharmacol. 325, 356-359 (1984)

4 Weiner, I.M. and Mudge, G.H.: Rena! tubular mechamisms for excretion of organic acids and bases. Am. J. Med. 36, 743-762 (1964)

5 Haber, E., Koerner, T., Page, L.B., Kliman, B. and Purnode, A.: Application of a radioimmunoassay for angiotensin I to the physiologic measurements of plasma renin activity in normal human subjects. $\rfloor$. Clin. Endocrinol. 29, 1349-1355 (1969)

6 Bailie, M.D. and Barbour, J.A.: Effect of inhibition of peptidase activity on distribution of intrarenal blood flow. Am. J. Physiol. 228, 850 $853(1975)$

7 Abe, Y., Miura, K., Imanishi, M., Yukimura, T., 
Komori, T., Okahara, T. and Yamamoto, K.: Effects of an orally active converting enzyme inhibitor (YS-980) on renal function in dogs. J. Pharmacol. Exp. Ther. 214, 166-170 (1980)

8 Ondetti, M.A., Rubin, B. and Cushman, D.W.:
Design of specific inhibitors of angiotensinconverting enzyme: New class of orally active antihypertensive agents. Science 196, 441-444 (1977) 